\title{
Mineral levels of Bali cattle (Bos javanicus) from different types of land in Bali, Nusa Penida, and Sumbawa Islands (Indonesia)
}

\author{
I NENGAH KERTA BESUNG ${ }^{1, \bullet}$, NI LUH WATINIASIH ${ }^{2}$, GUSTI NGURAH KADE MAHARDIKA ${ }^{3}$, \\ KADEK KARANG AGUSTINA ${ }^{4}$, NI KETUT SUWITI ${ }^{5}$ \\ ${ }^{1}$ Department of Bacteriology, Faculty of Veterinary Medicine, Universitas Udayana. Jl. PB Sudirman, Denpasar 80226, Bali, Indonesia. \\ Tel.: +62-361-223791, `email: kerta_besung@unud.ac.id \\ ${ }^{2}$ Departement of Biology, Faculty of Mathematics and Natural Sciences, Universitas Udayana. Jl. Raya Kampus Unud No. 9, Kampus Bukit Jimbaran, \\ Badung 80361, Bali, Indonesia \\ ${ }^{3}$ Animal Biomedical and Molecular Biology Laboratory, Faculty of Veterinary Medicine, Universitas Udayana. J1 Sesetan Markisa 6, Denpasar 80225, \\ Bali, Indonesia \\ ${ }^{4}$ Department of Veterinary Public Health, Faculty of Veterinary Medicine, Universitas Udayana. Jl. PB Sudirman, Denpasar 80226, Bali, Indonesia \\ ${ }^{5}$ Bali Cattle Research Center, Universitas Udayana. Jl. Goris, Denpasar 80226, Bali, Indonesia
}

Manuscript received: 8 July 2019. Revision accepted: 12 September 2019.

\begin{abstract}
Besung INK, Watiniasih NL, Mahardika GNK, Agustina KK, Suwiti NK. 2019. Mineral levels of Bali cattle (Bos javanicus) from four different types of land in different rearing areas in Bali, Nusa Penida, and Sumbawa Islands (Indonesia). Biodiversitas 20: 2931-2936. This study aims to prove that the mineral level of Bali cattle in serum is dependent on the origin and raising habitat. Serum samples were collected from three islands in Indonesia, i.e. Bali, Nusa Penida, and Sumbawa. Samples from Bali were further classified into four different areas (i.e. agroforestry, perennial plantation, horticultural plantation, and rice field). Blood samples were collected in the jugular vein without anticoagulant. The contents of macrominerals $(\mathrm{Ca}, \mathrm{Mg}, \mathrm{Na}, \mathrm{K}, \mathrm{P})$ and microminerals $(\mathrm{Fe}, \mathrm{Cu}, \mathrm{Zn}, \mathrm{Co}, \mathrm{Mn})$ were measured using the flame method in atomic absorption spectrophotometer. The results showed that the level of phosphor (P) macromineral and all microminerals under study were influenced by the origin of cattle. The macrominerals are statistically varied in different cattle raising environments. The same is also valid for all microminerals, with an exception of Fe. All mineral levels under study were statistically equal in male and female Bali cattle. Phosphor macromineral and all microminerals levels were origin and environment-dependent. Supplementation of deficient minerals in a certain area and land type is recommended to improve the performance of Bali cattle.
\end{abstract}

Keywords: Bali cattle, macromineral, micromineral

\section{INTRODUCTION}

Knowledge on mineral level of Bali cattle is paramount in the improvement of its production. This breed is purely derived from domestication of wild banteng (Bos javanicus) around $3500 \mathrm{BC}$ in Indonesia (Syed-Shabthar et al. 2013) with no evidence for zebu breed introgression (Mohamad et al. 2012). These indigenous cattle are most suitable for small farming with low input as well as betteradapted compared to Bos indicus and Bos taurus in Indonesia (McCool 1992; Martojo 2012). Since it represents around a quarter of cattle population in the country (Purwantara et al. 2012), Bali cattle becomes an important breed in self-sustained beef production of the nation. The breed is indeed well-adapted in that tropical country. It has also superiority in fertility, conception rate, and adaptability to harsh environments (Sutarno and Setyawan 2015).

Bali cattle are raised mainly in Bali to East Nusa Tenggara. The land condition of this archipelagic provinces is different from each other. We conducted the study in three islands, namely Bali, Nusa Penida, and Sumbawa of Indonesia.
Bali island is mostly covered by mountainous and hilly areas. The chain of mountains extends from west to east. Some mountains are active volcanoes. The island of Bali has a varied topographic surface such as ramps, hills, and highlands. The rainfall is quite high, which resulted in many tropical forests on this island. There is a variegated plant dense forest with hardwood trees and grasses (Distan 2010).

Nusa Penida consists of Mediterranean brown soil type with limestone base. The calcareous soil is dominant spread throughout the island. Patchy grey-brown alluvial soil is found in the alluvial plain covering around $10 \%$ of the island. The dominant vegetation is mangroves in the coastal regions and forest in the hilly areas, interspersed with grass. The island has low rainfall and prolonged dry season, that causes limited vegetation, so most of the island appears as barren fields (Klungkungkab 2018).

Sumbawa Regency has relatively short rainfall between February and April. The long dry season causes limited vegetation to grow. Sprawling grass tends to turn yellow in the dry season. Sumbawa Island has a lot of lands used for livestock and expanse of pasture/grazing as the development of animal husbandry in the Sumbawa district. Rearing cattle in this place different from most regions in 
Indonesia. Livestock is not stabled but released on public grazing areas known by the Sumbawa community as "lar" (Kusuma 2018).

The provision of quality feed is one contributing factor in increasing the productivity of livestock. Growing animals need adequate nutrition to support maximum growth. In this case, the feeding strategy should be adjusted to their needs in terms of both quantity and quality. Conversely, cattle feed shortage can lead to a deficiency disease. The levels of minerals in cattle are the number of minerals consumed, the number of minerals that can be metabolized body and the availability of minerals in the environment should be influencing in the livestock growth (Besung 2013).

Mineral elements have crucial role in animal production and health. Minerals, in the form of chemical compounds, are naturally available through geological processes in the form of simple salts to very complex silicates (Khan et al. 2007, 2008). Minerals are grouped into macrominerals, i.e. calcium $(\mathrm{Ca})$, magnesium $(\mathrm{Mg})$, sodium $(\mathrm{Na})$, potassium $(\mathrm{K})$, and phosphor $(\mathrm{P})$, and microminerals, i.e. iron $(\mathrm{Fe})$, copper $(\mathrm{Cu})$, zinc $(\mathrm{Zn})$, copper $(\mathrm{Co})$, and manganese $(\mathrm{Mn})$ (Maradal et al. 2004). Minerals have a special role in ensuring efficient growth, reproduction and immunocompetence in animals (Peres et al. 2001; Moeini et al. 2011). The concentration of some trace minerals is affected during the transitional period, especially around the time of parturition. Macrominerals are required in the development of bones and teeth and are also found in lipids, proteins, muscle, and tissue, while macrominerals have a great impact on animal's reproductive physiology and its imbalance causes various problems leading to lower reproductive efficiency (Kumar et al. 2011). Mineral level can also be used for rapid and accurate in-vivo classification of cattle according to organic and nonorganic production type (Rodriguez-Bermudez et al. 2018).

International report on mineral level of Bali cattle is not available. It is well-documented that mineral level is dependent on genetic trait (Ahlberg et al. 2014) and feed (Adams 1975; Khan et al. 2007; Sath et al. 2013; Manuelian et al. 2017). Moreover, the interaction within age and species, age and sex, and species and sex have been reported to have significant influence on mineral level (Giuffrida-Mendoza et al. 2007). Moreover, (Morgan and Connolly 2013) as well as (Singh and Schulze 2015) described that the level of various minerals in plants depends on the soil structure. Therefore, we would like to prove that the mineral level of Bali cattle in serum is dependent on the origin, raising habitat, and sex. To test this hypothesis, we collect serum samples from three islands in Indonesia, Bali, Nusa Penida and Sumbawa, four different areas, i.e. agroforestry, perennial plantation, horticulture plantation and rice field, and different sex.

\section{MATERIALS AND METHODS}

\section{Ethical clearance}

This research was accepted in the Ethical Commission for the Use of Animals in Research and Education of the Faculty of Veterinary Medicine, Udayana University, Indonesia with Ref No. 371/UN14.2.9/PD/2019.

\section{Sampling location}

Male and female Bali cattle of 8-24 months of age were collected from Bali, Nusa Penida, and Sumbawa Islands of Indonesia (Figure 1). Samples from Bali were categorized based on variation of raising environment, i.e. agroforestry, perennial plantation, horticultural plantation, and rice field. Agroforestry cattle raising means the location is close to forest distancing less than 500 meters. Perennial plantation means that cattle raising in multiyear plantation such as coconut, cacao, coffee, or alike. Horticultural plantation means that the cattle are stalled in an environment of horticulture such as bean, corn, vegetables, cassava, or alike.

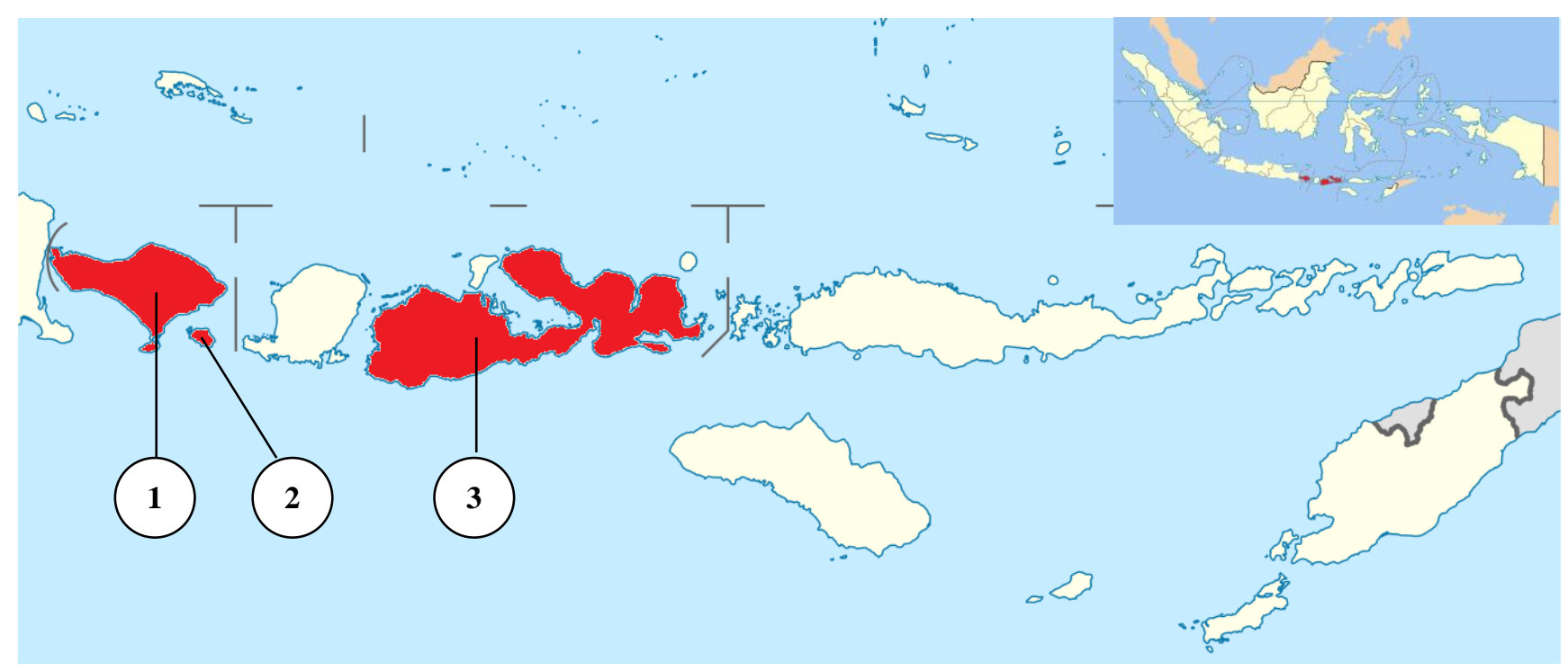

Figure 1. Sample location were in: (1) Bali, (2) Nusa Penida, and (3) Sumbawa islands of the Lesser Sunda Islands, Indonesia 
Table 1. The average and standard deviation of macro- and micromineral levels of Bali cattle from Bali, Nusa Penida, and Sumbawa islands of Indonesia

\begin{tabular}{|c|c|c|c|c|c|}
\hline \multirow{2}{*}{ Island } & \multicolumn{5}{|c|}{ Macrominerals (mg/dL) } \\
\hline & $\mathbf{C a}$ & Mg & $\mathbf{N a}$ & $\mathbf{K}$ & $\mathbf{P}$ \\
\hline Bali & $11.93 \pm 3.65$ & $23.48 \pm 3.05$ & $20.03 \pm 2.96$ & $18.88 \pm 7.48$ & $14.00 \pm 8.18^{\mathrm{a}}$ \\
\hline Nusa Penida & $11.88 \pm 1.84$ & $23.79 \pm 1.68$ & $20.09 \pm 1.66$ & $21.13 \pm 1.77$ & $8.14 \pm 1.17^{\mathrm{a}}$ \\
\hline Sumbawa & $11.88 \pm 2.89$ & $24.09 \pm 2.03$ & $20.16 \pm 4.08$ & $23.38 \pm 3.97$ & $2.28 \pm 2.66^{\mathrm{b}}$ \\
\hline \multirow[t]{2}{*}{ Total } & $11.88 \pm 3.03$ & $23.90 \pm 2.33$ & $20.12 \pm 3.66$ & $22.01 \pm 5.38$ & $5.85 \pm 6.94$ \\
\hline & \multicolumn{5}{|c|}{ Microminerals (mg/dL) } \\
\hline Bali & $0.12 \pm 0.2^{\mathrm{c}}$ & $0.24 \pm 0.09^{c}$ & $0.07 \pm 0.02^{\mathrm{b}}$ & $0.08 \pm 0.02^{c}$ & $0.19 \pm 0.040^{c}$ \\
\hline Nusa Penida & $0.27 \pm 0.17^{\mathrm{ab}}$ & $0.29 \pm 0.03^{\mathrm{ab}}$ & $0.07 \pm 0.01^{\mathrm{ab}}$ & $0.49 \pm 0.04^{\mathrm{b}}$ & $0.69 \pm 0.54^{\mathrm{b}}$ \\
\hline Sumbawa & $0.47 \pm 0.77^{\mathrm{a}}$ & $0.36 \pm 0.27^{\mathrm{a}}$ & $0.08 \pm 0.03^{\mathrm{a}}$ & $0.89 \pm 0.05^{\mathrm{a}}$ & $2.16 \pm 0.40^{\mathrm{a}}$ \\
\hline Total & $0.36 \pm 0.65$ & $0.32 \pm 0.23$ & $0.08 \pm 0.03$ & $0.64 \pm 0.36$ & $1.52 \pm 0.96$ \\
\hline
\end{tabular}

Note: Different annotations $(a, b, c)$ in a column indicate statistical different $(\mathrm{p}<0.05)$ from the highest to the lowest values, respectively

\section{Blood samples}

The samples were collected following purposive sampling method. One hundred twenty sera of Bali cattle's were collected in Bali from four different land types, i. e. agroforestry, perennial plantation, horticultural plantation, and rice field. The number of samples from each land type was 30. The numbers of samples from Nusa Penida and Sumbawa were 40 and 300. The proportion of male and female in each area and island were $50 \%$. Blood samples were collected in the jugular vein. After proper clotting, the blood samples were centrifuged at $3500 \mathrm{rpm}$ for 15 minutes and the serum samples were stored at $-20^{\circ} \mathrm{C}$ until analyses. Before measurement, serum samples were deproteinized by supplementing trichloracetic acid at a 1:1 ratio. After centrifugation, the content of of macrominerals $(\mathrm{Ca}, \mathrm{Mg}$, $\mathrm{Na}, \mathrm{K}, \mathrm{P}$ ) and microminerals ( $\mathrm{Fe}, \mathrm{Cu}, \mathrm{Zn}, \mathrm{Co}, \mathrm{Mn}$ ) in the supernatant were measured using the flame method of an atomic absorption spectrophotometer (Unicam Solar 939, UK) as previously described (Skalicka et al. 2016).

\section{Statistical analysis}

All statistical analyses were performed in SPSS 10.0 for Windows. One-way analysis of variance (ANOVA) was performed to compare differences between means.

\section{RESULTS AND DISCUSSION}

The average and standard deviation of macro and micromineral levels of Bali cattle from Bali, Nusa Penida, and Sumbawa islands are shown in Table 1. The result shows that macrominerals level of $\mathrm{Ca}, \mathrm{Mg}, \mathrm{Na}, \mathrm{K}$, and $\mathrm{P}$ of Bali cattle were $11.88 \pm 3.03,23.90 \pm 2.33,20.12 \pm 3.66$, $22.01 \pm 5.38$ and $5.85 \pm 6.94 \mathrm{mg} / \mathrm{dL}$, respectively, while those of microminerals of $\mathrm{Cu}, \mathrm{Zn}, \mathrm{Mn}, \mathrm{Fe}$, and $\mathrm{Co}$ were $0.36 \pm 0.65,0.32 \pm 0.23,0.08 \pm 0.03,0.64 \pm 0.36$, and $1.52 \pm 0.96$ $\mathrm{mg} / \mathrm{dL}$, respectively. Statistical significant difference was in phosphor $(\mathrm{P})$ macromineral, as well as in all microminerals under study $(\mathrm{p}<0.05)$. The highest value of phosphor macromineral was in Bali cattle from Bali, while the lowest from Sumbawa. The highest all microminerals were in Bali cattle from Sumbawa, while the lowest from Bali.
The pattern of raising cattle on Bali, Nusa Penida and Sumbawa Islands are different. Cattle that are rearing on the island of Bali and Nusa Penida placed in cages or tied up in a cage. In contrast with cattle on Sumbawa Island, which was released in the pasture which is called "lar"(Kusuma 2018). Farmers in Sumbawa do not provide the special cage, but the cattle are let loose and give birth in the wild.

The different cattle raising patterns cause different feed. In caged cattle, farmers provide feed regularly as needed. Farmers are looking for grass and legumes for their cows. In extensive cattle raising, the animal feed consists of what available in nature. There are no additional minerals or additional drugs. These conditions would have an impact on the type and quality of the eaten food. The poor quality of feed will affect the body condition and mineral content in blood plasma. Seventy percent of the productivity of Bali cattle, especially for growth and production capacity is influenced by environmental factors. Sixty percent of these environmental factors are feed, nutrient content, and ration formulation technology. This shows that the ability of Bali cattle to absorb nutrients greatly affects their productivity (Bianca et al. 2018).

Mineral elements are very needed for physiological processes of livestock, especially in ruminants whose feed sources are forage (Darmono 2007). The tendency of farmers to raise Bali cattle, provide feed to their livestock, with food sources in their environment will affect the levels of minerals in the body of animals (Sujani et al. 2014). When cattle are traditionally maintained by grazing and only getting the feed from grasslands, the availability of minerals in the soil and animal feed grass needs to be considered. Provision of additional minerals to ruminants that live in areas with mineral-poor soil needs to be done. Leguminosae has a relatively high mineral content (Prabowo et al. 1984).

Macromineral $(\mathrm{Ca}, \mathrm{Mg}, \mathrm{Na}, \mathrm{K}$, and $\mathrm{P}$ ) concentrations in the serum of Bali cattle raised in different environment, i.e. agroforestry (AF), perennial plantation (PP), horticultural plantation (HP) and rice field (RF) are illustrated in Figure 2. Cattle raised in ricefield have the lowest concentration of $\mathrm{Ca}, \mathrm{Mg}, \mathrm{K}$, and $\mathrm{P}$, while $\mathrm{Na}$ value was statistically indifferent in all land type. The $\mathrm{Ca}, \mathrm{Mg}$, and $\mathrm{K}$ 
concentrations were indifferent in agroforestry, perennial plantation, and horticultural plantation. The ricefield is overharvested that leads to low concentration of some minerals such as $\mathrm{Ca}, \mathrm{Mg}, \mathrm{K}$, and $\mathrm{P}$. This needs to be studied further. The cattle raised in the agroforestry have statistically the highest phosphor level, while those raised in perennial plantation and horticultural plantation were statistically equal.

Micromineral $(\mathrm{Cu}, \mathrm{Zn}, \mathrm{Mn}, \mathrm{Fe}$, and $\mathrm{Co})$ concentrations in the serum of Bali cattle raised in different environment are presented in Figure 3. The concentration of $\mathrm{Fe}$ is statistically indifferent in all land types. The level of $\mathrm{Cu}$ was the lowest in horticulture plantation, while others are statistically equal. The $\mathrm{Zn}$ level was highest in horticulture plantation, the lowest in rice field, while the other raising environments are equal. Mn was lower in AF and RF and higher in PP and HP, while the level of mineral in both AFRF and PP-HP are statistically insignificant. The highest
Co level was in serum of cattle from horticulture plantation, while from other environments were statistically equal. The level of macromineral and micromineral concentrations in the serum of Bali cattle of different sexes are presented in Figure 4. No significant differences in all mineral concentrations in male and female Bali cattle.

Here we provide mineral level database of Bali cattle for scientifically sound improvement of its performance. The result is valuable in the management of mineral in the feeding of the animal, particularly what minerals are missing in particular island or cattle raising environment. We previously have published the hormonal level of this unique cattle breed (Suwiti et al. 2017). We found that the level of bovine growth hormone in Bali cattle was low and statistically equal from all origins, and that the difference was related to sex and management practices (Suwiti et al. 2017).

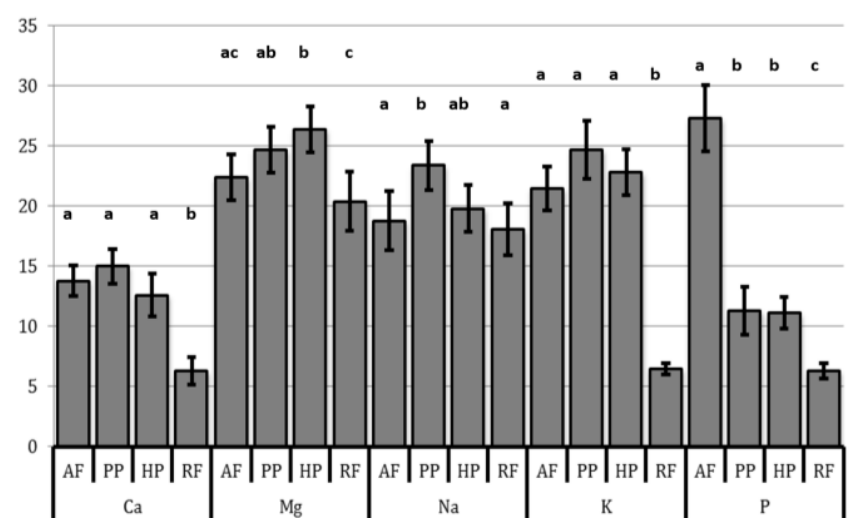

Figure 2. Macromineral ( $\mathrm{Ca}, \mathrm{Mg}, \mathrm{Na}, \mathrm{K}$, and $\mathrm{P})$ concentrations $(\mathrm{mg} / \mathrm{dL})$ in the serum of Bali cattle raised in different environment, i.e. agroforestry (AF), perennial plantation (PP), horticulture plantation (HP), and rice field (RF). Different annotations $(\mathrm{a}, \mathrm{b}, \mathrm{c})$ in each mineral indicate statistical different $(\mathrm{p}<0.05)$

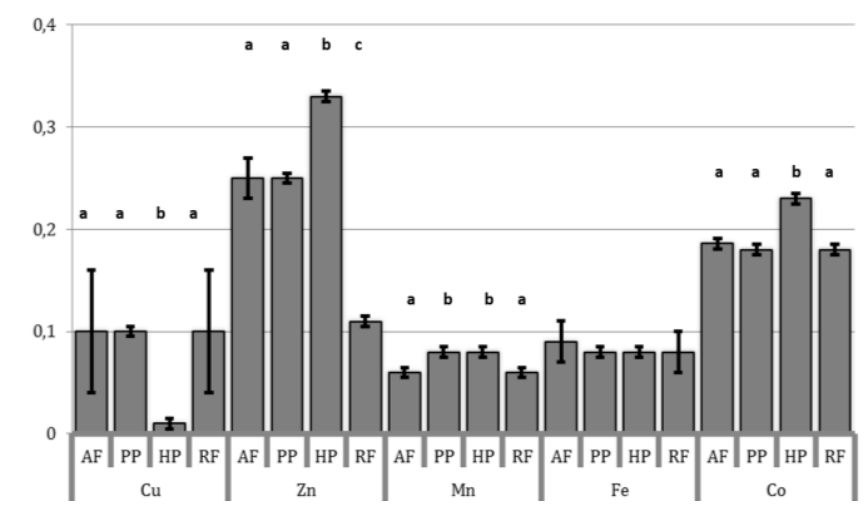

Figure 3. Micromineral $(\mathrm{Cu}, \mathrm{Zn}, \mathrm{Mn}, \mathrm{Fe}$, and $\mathrm{Co})$ concentrations $(\mathrm{mg} / \mathrm{dL})$ in the serum of Bali cattle raised in different environment, i.e. agroforestry (AF), perennial plantation (PP), horticulture plantation (HP), and rice field (RF). Different annotations $(\mathrm{a}, \mathrm{b}, \mathrm{c})$ in each mineral indicate statistical different $(\mathrm{p}<0.05)$.
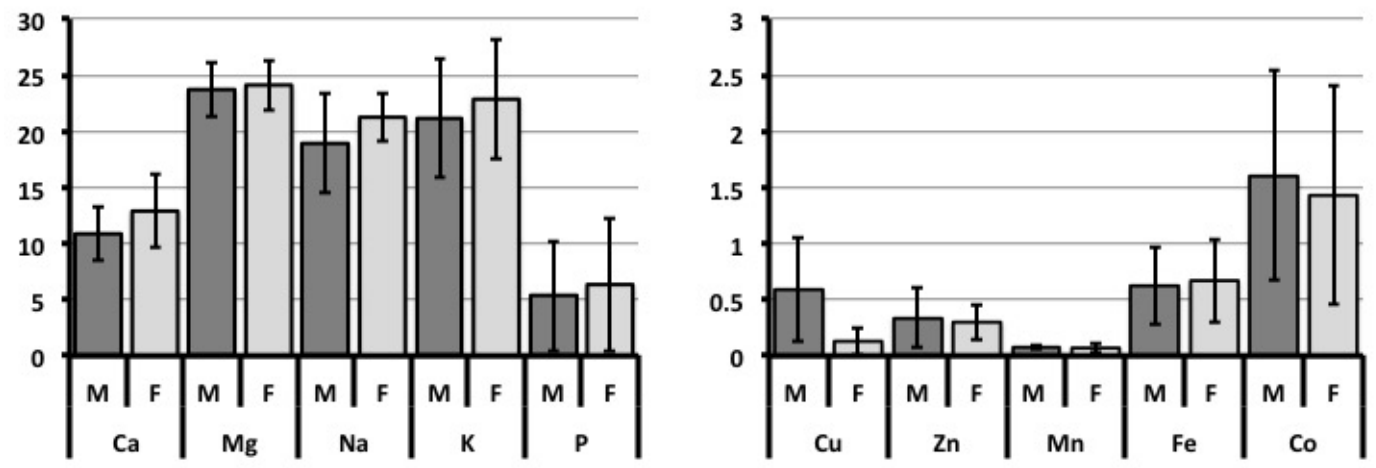

Figure 4. Macromineral (left) and micromineral (right) concentrations (mg/dL) in the serum of different sex of Bali cattle. Male and female animal data were dark- and light grey filled, respectively. Error bars of standard deviations were shown 
In this study, we hypothesized that the mineral level is dependent on the islands and land type. That is particularly valid for phosphor (P) macromineral as well as all microminerals. The macrominerals are statistically varied in different cattle raising environments. The same is also valid for all microminerals, with an exception of Fe. It seems that phosphor macromineral is of high concentration from feed in Bali, however, it has low concentration of all microminerals. The land type has influenced the mineral level for macromineral $\mathrm{Ca}, \mathrm{Mg}, \mathrm{K}$, and $\mathrm{P}$, as well as all microminerals, with an exception of Fe. Agroforestry is rich on phosphor macromineral, while rice-field environment is poor on $\mathrm{Ca}, \mathrm{Mg}, \mathrm{K}, \mathrm{P}$, and $\mathrm{Zn}$. The horticultural environment is deficient in $\mathrm{Cu}$. Moreover, all mineral levels under study were sex-independent.

Mineral balance is the issue in the supplementation of mineral in the feeding. Many microminerals play a role in the body as cofactors of enzymes involved in controlling free radicals within the body and are vital to antioxidant capabilities (Goff 2018). Those same minerals, when consumed in excess, can become pro-oxidants in the body, generating destructive free radicals. Complex interactions between minerals can compromise the effectiveness of a diet in promoting health and productivity of the cow (Goff 2018). Other group reported that supplementation of some minerals $(\mathrm{Ca}, \mathrm{P}, \mathrm{Zn}, \mathrm{Mn}$, and $\mathrm{Cu})$ might have minor effect on the performance of Bali cattle as it has been proven in dairy cattle Nellore cattle (Prados et al. 2017). This research might have been done without any knowledge on the database of mineral level in the animal. Spears (Spears 1995) recommended supplementation of trace mineral to improve cattle health. However, the effect of trace mineral supplementation, for example, Selenium (Se) which is not measured in our study, depends on physiological stage, Se status of animals, type and content of Se and types of Se administration (Mehdi and Dufrasne 2016).

Another minor finding of our study is that sex has no influence on mineral level. Therefore, it is certain that the mineral level largely depends on genetic (Ahlberg et al. 2014) and feeds (Adams 1975; Sath et al. 2013; Manuelian et al. 2017). It has been known that minerals and trace element content varies in cattle feeds (Adams 1975)

A weakness of this study might have been the choice of serum the detect all mineral level. Another researcher, (Herold et al. 2018), suggested the use of fecal samples to detect $\mathrm{Ca}, \mathrm{P}$ and $\mathrm{Mg}$ intake, while urine is the best substrate for $\mathrm{Na}$ and $\mathrm{K}$.

In conclusion, the macrominerals are statistically varied in different cattle raising environments. The same is also valid for all microminerals, with an exception of Fe. Phosphor macromineral and all micromineral levels were origin and environment-dependent. Supplementation of deficient minerals in a certain area and land type is recommended to improve the performance of Bali cattle. Further research is needed to compare the level of various minerals in serum to fecal and urine samples.

\section{ACKNOWLEDGEMENTS}

This research was funded by Directorate General of Higher Education of Indonesia through PENPRINASMP3EI No.175 A.19/UN 14. 2/PNL.01.03.00/2013 and Directorate General Research and Development Strengthening, The Ministry of Research and Higher Education, Indonesia of Strategic National Institution Research No 171.95/UN.14.4.A/LT/2018.

\section{REFERENCES}

Adams RS. 1975. Variability in mineral and trace element content of dairy cattle feeds. J Dairy Sci 58: 1538-1548.

Ahlberg CM, Schiermiester LN, Howard TJ, Calkins CR, Spangler ML. 2014. Genome-wide association study of cholesterol and poly- and monounsaturated fatty acids, protein, and mineral content of beef from crossbred cattle. Meat Sci 98: 804-814.

Besung INK. 2013. Analisis faktor tipe lahan dengan kadar mineral serum sapi Bali. Buletin Vet Udayana 5(2): 96-106. [Indonesian]

Bianca VJ, Besung INK, Suarjana IGK, Suwiti NK. 2018. Jumlah Bakteri coliform pada sapi bali menurut tingkat kedewasaan dan lokasi peternakan di Nusa Penida. Buletin Vet Udayana 10(1): 45-49. [Indonesian]

Darmono. 2007. Penyakit defisiensi mineral pada ternak ruminansia dan upaya pencegahannya. J Litbang Pertanian 26(3): 104-108. [Indonesian]

Distan. 2010. Kegiatan Sistem pertanian terintegrasi (Simantri) di Provinsi Bali. Dinas Pertanian Tanaman Pangan Provinsi Bali, Denpasar. [Indonesian]

Giuffrida-Mendoza M, Arenas de Moreno L, Uzcategui-Bracho S, Rincon-Villalobos G. and Huerta-Leidenz N. 2007. Mineral content of longissimus dorsi thoracis from water buffalo and Zebu-influenced cattle at four comparative ages. Meat Sci 75: 487-493.

Goff JP. 2018. Invited review: Mineral absorption mechanisms, mineral interactions that affect acid-base and antioxidant status, and diet considerations to improve mineral status. J Dairy Sci 101: 2763-2813.

Herold A, Pieper L, Muller AE, Staufenbiel R. 2018. Mineral concentrations in cattle in different sample media with emphasis on fecal analysis. Tierarztl Prax Ausg G Grosstiere Nutztiere 46: 221228.

Khan ZI, Ahmed K, Ashraf M, Valeem EE, Javed I. 2008. A comparative study on mineral status of blood plasma of small ruminants and Pastures in Punjab, Pakistan. Pak J Bot 41: 67-72.

Khan ZI, Ashraf M, Ahmad K, Mustafa I, Danish M. 2007. Evaluation of microminerals composition of different grasses in ration to livestock requirements. Pak J Bot 39(3): 719-728.

Klungkungkab.go.id. 2018. Kondisi geografis. available at http://klungkungkab.go.id/page/kondisi-geografis.html [7 Sep 2019].

Kumar S, Pandey AK, Razzaque WAA, Dwivedi DK. 2011. Importance of micro minerals in reproductive performance of livestock. Vet World 4: 230-233.

Kusuma TM. 2018. Dampak penurunan luas areal lar badi terhadap kondisi sosial ekonomi peternak sapi bali di Desa Lopok Kecamatan Lopok Kabupaten Sumbawa Besar. [Thesis]. Brawijaya University, Malang. [Indonesian]

Manuelian CL, Curro S, Penasa M, Cassandro M, De Marchi M. 2017. Characterization of major and trace minerals, fatty acid composition, and cholesterol content of Protected Designation of Origin cheeses. J Dairy Sci 100: 3384-3395.

Maradal AB, Yadav PS, Vanita K. 2004. Mineral status of buffaloes under farm feeding condition of Faridabad district of Haryana state. Indian J Anim Nutr 21: 104-110.

Martojo H. 2012. Indigenous Bali cattle is most suitable for sustainable small farming in Indonesia. Reprod Domest Anim 47(Suppl 1): 1014.

McCool C. 1992. Buffalo and Bali cattle--exploiting their reproductive behaviour and physiology. Trop Anim Health Prod 24: 165-172.

Mehdi Y, Dufrasne I. 2016. Selenium in cattle: A review. Molecules 21: 545. 
Moeini MM, Kiani A, Karami H, Mikaeili E. 2011. The effect of selenium administration on the selenium, copper, iron and zinc status of pregnant heifers and their newborn calves. J Agric Sci Tech 13: 5359.

Mohamad K, Olsson M, Andersson G, Purwantara B, van Tol HT, Rodriguez-Martinez H, Colenbrander B, Lenstra JA. 2012. The origin of Indonesian cattle and conservation genetics of the Bali cattle breed. Reprod Domest Anim 47(Suppl 1): 18-20.

Morgan JB, Connolly EL. 2013. Plant-soil interactions: Nutrient uptake. Nat Edu Knowl 4(8): 2.

Peres JM, Bureau F, Neuville D, Arhan P, Bougle D. 2001. Inhibition of zinc absorption by iron depends on their ratio. J Trace Elem Med Biol 15: 237-241.

Prabowo A, Van Eys JE, Mathius IW, Rangkuti M, Johnson WI. 1984. Studies on the mineral nutrition on sheep in West Java. In: Indonesia Small Ruminant-CRSP Working Paper, Bogor. [Indonesia]

Prados LF, Sathler DFT, Silva BC, Zanetti D, Valadares FSC, Alhadas HM, Detmann E, Santos SA, Mariz LDS, Chizzotti ML. 2017. Reducing mineral usage in feedlot diets for Nellore cattle: II. Impacts of calcium, phosphorus, copper, manganese, and zinc contents on intake, performance, and liver and bone status. J Anim Sci 95: 17661776.

Purwantara B, Noor RR, Andersson G, Rodriguez-Martinez H. 2012. Banteng and Bali cattle in Indonesia: status and forecasts. Reprod Domest Anim 47(Suppl 1): 2-6.

Rodriguez-Bermudez R, Herrero-Latorre C, Lopez-Alonso M, Losada DE Iglesias R, Miranda M. 2018. Organic cattle products: Authenticating production origin by analysis of serum mineral content. Food Chem 264: 210-217.

Sath K, Pauly T, Holtenius K. 2013. Mineral status in cattle fed rice straw and para grass combined with different levels of protein derived from cassava foliage. Asian-Australas J Anim Sci 26: 59-64.

Singh B, Schulze DG. 2015. Soil Minerals and plant nutrition. Nat Edu Knowl 6(1): 1.

Skalicka M, Nad P, Samudovska AH, Bujnak L. 2016. Micro mineral concentrations of dairy cows in selected areas from Slovak Republic. J Vet Sci Tech 7(1): 1000289.

Spears JW. 1995. Improving cattle health trough trace mineral supplementation. In: The Range Beef Cow Symposium XIV, Nebraska.

Sujani NKD, Piraksa IW, Suwiti NK. 2014. Profile magnesium and copper mineral in blood serum of Bali cattle reared on dry land. Buletin Vet Udayana 6(2): 119-122. [Indonesian]

Sutarno, Setyawan AD. 2015. Genetic diversity of local and exotic cattle and their crossbreeding impact on the quality of Indonesian cattle. Biodiversitas 16: 327-354. [Indonesia]

Suwiti NK, Besung INK, Mahardika GN. 2017. Factors influencing growth hormone levels of Bali cattle in Bali, Nusa Penida, and Sumbawa Islands, Indonesia. Vet World 10: 1250-1254.

Syed-Shabthar SM, Rosli MK, Mohd-Zin NA, Romaino SM, Fazly-Ann ZA, Mahani MC, Abas-Mazni O, Zainuddin R, Yaakop S, Md-Zain BM. 2013. The molecular phylogenetic signature of Bali cattle revealed by maternal and paternal markers. Mol Biol Rep 40: 51655176 